\title{
Misiunea Bisericii Creștine in spațiul arab pre-islamic
}

\section{Oliviu-Petru BOTOI}

Abstract: The Christian Church of the first centuries knew a quick and intense development within the oriental Arabian-Syrian area, maintaining a close connection with the Apostolic Church of Jerusalem. The Christianization of this geographic area led to the familiarity of the Arabian population with the Christian tenets, contributing to the genesis and affirmation of the theology thesaurus in the Syriac language. It is very important for our research to know the existence of the Christian communities in this pre-Islamic Arabian space. The Christian Churches entrance into the shadows within the Arabian communities was due to the occurrence and the spread of Islam.

Keywords: primary Christian communities, Arabian populations, Non-Chalcedonian Churches, heresy 


\section{Oliviu-Petru BOTOI}

\section{Introducere}

Spațiul geografic al Arabiei reprezintă astăzi centrul lumii islamice, locul în care s-a născut și dezvoltat islamul și locul din care s-a răspândit spre Orientul Îndepărtat, Africa și Europa, începând cu secolul al VIII-lea. Până în secolul al VII-lea, structura religioasă a acestui areal geografic era una extrem de diversificată. Pe de o parte, comunitați întregi de evrei s-au refugiat și s-au organizat în cetățile comerciale ale Arabiei, devenind cei mai influenți negustori; de asemenea creștinismul se răspândise destul de mult în zonele urbane, dovedindu-se un factor de coagulare a celor cu preocupări cărturărești și a elitelor politice. Pe de altă parte, dinspre zonele adânci ale deșertului, populațiile beduine semnalau încă practici religioase autohtone politeiste. Creștinismul receptat și practicat de aceste populații arabe încă de la început a cunoscut forme eterodoxe, fiind suprapus peste moștenirea religioasă păgână arabă şi confundat într-o oarecare măsură cu iudaismul, dat fiind faptul că aceste două religii erau monoteiste. Lucrarea de faţă își propune să realizeze o radiografie sumară a răspândirii creștinismului în spațiul arab și în același timp să demonstreze caracterul sincretic și eterodox al dogmelor creștinilor arabi.

\section{Răspândirea creștinismului în spațiul arab}

Principalul şi cel mai important document pentru descrierea răspândirii creştinismului în primul veac al erei creştine îl reprezintă Faptele Apostolilor. Însă, aşa cum preciza şi cardinalul Jean Daniélou, se impun câteva remarci în ceea ce priveşte perspectiva din care autorul Faptelor a tratat evenimentele pe care le-a descris în scrierea sa. De formaţie elenă şi format în spiritul paulin, Sfântul Apostol 
Luca a evitat să descrie prea mult iudeo-creştinismul primului secol' ${ }^{1}$, întrând astfel într-un con de umbră Biserica Ierusalimului şi tinerele comunități creştine mai îndepărtate din Orientul Apropiat şi Mijlociu, întemeiate prin misiunea celorlalţi Apostoli. În acest fel, creionarea creştinismului de limbă aramaică sau creştinismului oriental rămâne imposibilă din surse canonice, iar singura cale prin care se pot decela aspecte ale acestor comunităţi creştine care vor deveni adevărate Biserici, rămâne cea a accesării tradiţiilor şi scrierilor necanonice la temelia cărora a stat până la un anumit punct rememorarea şi păstrarea învăţăturilor Mântuitorului. Spre exemplu, în Fapte, Sfântul Apostol Iacob, ,fratele Domnului”, nu apare decât o singură dată (excluzând evenimentul Cinzecimii la care erau adunaţi toţi Apostolii), deşi se cunoaşte cert faptul că Iacob a fost „stâlpul Bisericii” din Ierusalim şi unul dintre cei care l-au cunoscut îndeaproape pe Hristos, era considerat un „calif” al Bisericii Ierusalimului de unde au izvorât toate celelalte Biserici². Autorul Faptelor 1-a însoțit pe Sfântul Pavel la Ierusalim, unde s-a întâlnit cu Iacob, care a adunat la el mulţimea (în mare parte a iudeilor) care a crezut în Domnul şi cărora Pavel le-a povestit minunile pe care le-a făcut Domnul prin el, între celelalte neamuri. Se observă că Pavel era străin de Biserica Ierusalimului, deoarece Apostolul Iacob îl încredinţează de râvna iudeilor convertiţi şi mai pe urmă îl înştiinţează şi de convertiţii care nu erau iudei, cărora le-a trimis o scrisoare în care i-a atenţionat asupra jertfelor idoleşti şi asupra desfrâului. De vreme ce Apostolul Iacob le-a scris, înseamnă că nu se referă doar la păgânii care locuiau în Ierusalim, ci şi la cei din alte părţi private de misiunea apostolică a lui Pavel. Doar la atât se limitează Apostolul Luca în relatarea din Fapte despre Iacob. Însă, alte documente necanonice din medii şi spaţii diferite, dar din aceeaşi

\footnotetext{
${ }^{1}$ Robert M. Royalty Jr., ,Heresy” in Second-Temple Judaism and Early Christianity, în „Concilium”, Christian Orthodoxy, nr. 2, 2014, pp. 38-39.

${ }^{2}$ Jaroslav Pelikan, Tradiţia creştină. O istorie a dezvoltării doctrinei. Vol. I: Naşterea tradiţiei universale (100-600), Traducere de Silvia Palade, Iaşi, Editura Polirom, 2004, p. 37.
} 


\section{Oliviu-Petru BOTOI}

perioadă istorică, oferă o poziţie privilegiată Apostolului Iacob3 . În Evanghelia evreilor, text legat de o comunitate iudeo-creştină din Egipt de la începutul secolului al II-lea ${ }^{4}$, „Iacov este cel căruia Hristos îi apare mai întâi"'s. „În Evanghelia după Toma, descoperită la Nag Hammadi, Iacov cel Drept este prezentat ca cel spre care trebuie să meargă Apostolii după Înălţare. Clement, în Hypotyposes, îl menţionează înaintea lui Ioan şi Petru, ca având primită gnoza ${ }^{6}$ de la Hristos înviat. (...) În scrierile pseudo-clementine, ce utilizează izvoare iudeo-creştine ebionite, Iacov este prezentat ca cel mai important personaj al Bisericii (Hom. Clem. I, 1)"”.

Un alt detaliu din Faptele Apostolilor care ne atrage atenţia este cel legat de numele lui Simon $(8,9)$ şi de numele lui Teudas ${ }^{8}(5,36)$, care erau iudei care au împrumutat idei iraniene dualiste ${ }^{9}$ sau poate fi vorba despre nişte emigranţi orientali care îşi practicau credinţele şi tehnicile păgâneşti în noul context socio-religios.

${ }^{3}$ Jean Daniélou, Biserica primară (De la origini până la sfârşitul secolului al treilea). Traducere din limba franceză de George Scrima, Bucureşti, Editura Herald, 2008, p. 15.

${ }^{4}$ Vezi E. Hennecke, Neutestamentliche Apokyphen in deutscber Uebersetzung, Ediţia a III-a, Tübingen, 1959, I, p. 107, apud. Jean Daniélou, op. cit., p. 15.

${ }^{5}$ Jean Daniélou, op. cit., p. 15.

${ }^{6}$ Pentru evitarea unei confuzii păguboase între gnoză și gnosticism în vederea înțelegerii autentice a conceptului de gnoză, vezi Gabriel Bunge, Părintele duhovnicesc şi gnoza creştină după avva Evagrie Ponticul, Traducere de diac. Ioan I. Ică jr., Sibiu, Editura Deisis, 2000, p. 14; Evagrie Ponticul, Tratatul practic. Gnosticul, Traducere de Cristian Bădiliţă, Bucureşti, Curtea Veche, 2009.

${ }^{7}$ Jean Daniélou, op. cit., p. 15.

${ }^{8}$ James Hastings, Dictionary of Christ and the Gospels, II, New York, Charles Scribners Sons - Edinburgh, T \& T Clark, 1908, p. 726. (Ediţie consultată la adresa web https://archive.org/stream/dictionaryofchri02hastuoft\#page/n7/ mode/2up în data de 29.06.2014)

${ }^{9}$ Jean Daniélou, op. cit., p. 26. 
Deşi nu trecuse mult timp de la evenimentul rusalian, misiunea de propovăduire a Apostolilor a trecut repede pragul Ierusalimului, ajungând destul de devreme în zonele siriane. Saul din Tars era pornit pe drumul Damascului pentru a prigoni comunitatea creştină din ace loc înainte de a i se arata Domnul şi înainte de a deveni apoi unul dintre cei mai râvnitori misionari creştini (Faptele Apostolilor, capitolul 9). Minunii prin care Saul devine Apostolul neamurilor, numit Pavel, îi urmează botezul şi încredinţarea misiunii pentru care a fost ales, urmând ca apoi să fie dus la Ierusalim pentru a-i cunoaşte pe ceilalţi Apostoli care au fost împreună cu Iisus. Între aceste două evenimente, cel al botezului din Damasc şi cel al întâlnirii cu ceilalţi Apostoli, în Epistola către Galateni mai aflăm un detaliu important pe care însuşi Pavel îl mărturiseşte: „Dar când a binevoit Dumnezeu, Care m-a ales din pântecele mamei mele, şi m-a chemat prin harul Său, să descopere pe Fiul Său întru mine, pentru ca să-L binevestesc la neamuri, îndată, nu am primit sfat de la trup şi de la sânge, nici nu $\mathrm{m}$-am suit la Ierusalim, la apostolii cei dinainte de mine, ci m-am dus în Arabia şi m-am întors iarăşi la Damasc, apoi după trei ani, m-am suit la Ierusalim ca să-l cunosc pe Chefa şi am rămas la el cincisprezece zile" (1,15-18). Este foarte greu să delimităm geografic Arabia în acest context. Pentru creştini şi iudei, şi nu numai, Arabia însemna cel mult partea nordică şi vestică a peninsulei, loc în care exista o civilizaţie urbană care nu era străină misiunii apostolice. În studiile româneşti clasice neo-testamentare Arabia este identificată cu Muntele Sinai, locul unde Moise a primit Legea de la Dumnezeu ${ }^{10}$. Însă, după ipoteza lui Daniélou, în vecinătatea Damascului şi chiar şi la Damasc, comunitatea creştină s-a constituit din sadochiţii

\footnotetext{
${ }^{10}$ Sabin Verzan, Sfântul Apostol Pavel. Istoria propovăduirii Evangheliei şi organizării Bisericii în epoca apostolică, Carte tipărită cu binecuvântarea Prea Fericitului Părinte Teoctist Patriarhul Bisericii Ortodoxe Române, Bucureşti, Editura Institutului Biblic şi de Misiune al Bisericii Ortodoxe Române, 1999, p. 42.
} 


\section{Oliviu-Petru BOTOI}

convertiţi ${ }^{11}$, care aşa cum afirma şi Philon, locuiau la sate. De aici, cardinalul francez ajunge să afirme o continuare a relaţiei dintre Pavel şi Kochba, în noul context al convertirii lui Saul. Comunitatea kochbiană activa în jurul Damascului, la aproximativ 15 kilometri. Or, se cunoaşte faptul că Damascul reprezenta graniţa dintre Imperiu şi Regatul nabateean ${ }^{12}$, deci se poate aşadar vorbi despre o încreştinare a spaţiului arab şi a unor triburi de populaţie arabă.

În mod cert, încreştinarea arabilor a depăşit limita graniţei dintre Imperiul Roman şi Orient, ajungând dincolo de Tigru, în Adiabene. În acest sens ne stă la îndemână un document important, anume Cronica din Arbela, scris în siriacă de către Mishiha Zkha, în secolul al VIlea ${ }^{13}$.

Aceste precizări nu sunt doar cazuri particulare de convertire la creştinism ale anumitor comunităţi puţin însemnate, ci reprezintă centre principale ale civilizaţiei din acele vremuri. Se cunoaşte în acest sens faptul că în Bostra, spre exemplu, exista un important centru creştin, legat de numele episcopului Beril care a fost întors de către Origen de la erezia antitrinitară în cadrul unui sinod, pe la

${ }^{11}$ Stephan Losch, Deitas Jesu und Antike Apotheose, Toltenburg, 1953, pp.7072. apud. Jean Daniélou, op. cit., p. 32.

${ }^{12}$ Pentru o radiografie istorică și religioasă a nabateenilor, vezi Mordechai Cogan, Haym Tadmor, Ashurbanipal Texts in the Collection of the Oriental Institute, în „Journal of Cuneiform Studies”, vol. 40, nr. 1, 1988, pp. 8496; Jean Starcky, The Nabataeans: A historical Sketch, în „The Biblical Archaeologist", vol. 18, nr. 4, dec., 1955, pp. 81-82; 84-106; Nelson Glueck, Nabatean Syria, în „Bulletin of the American Schools of Oriental Research, nr. 85, feb., 1942, pp. 3-8. Chrystian Boyer, Pétra, capitale des Nabatéens, în „La Caravane virtuelle”, 26 mai 2006, articol consultat la adresa web http:// www.interbible.org/interBible/caravane/voyage/2006/voy_060526.htm); ***, Dicţionar enciclopedic al Bibliei, Transpunere românească de Dan Sluşanschi, Bucureşti, Editura Humanitas, 1999, p. 431. Numele nabateenilor se leagă şi de cel al Sfântului Ioan Botezătorul şi de cel al Sfântului Apostol Pavel.

${ }^{13}$ Jean Daniélou, op. cit., p. 65. 
anul $244^{14}$. După câţiva ani, Origen mai participă la un sinod care de această dată isşi propunea să clarifice o dilemă teologică, anume aceea dacă sufletul supravieţuieşte morţii corpului ${ }^{15}$. Într-un alt sinod Origen apără acuzaţiile aduse unui episcop pe nume Heraclide care repetă erorile dogmatice care au fost îndreptate deja la celelalte două sinoade de dinainte. Tradiţia acestui centru a continuat şi a prosperat din punct de vedere teologic, majoritatea specialiştilor (Harnach, Schneider, Kretschmar ${ }^{16}$ fiind de acord asupra originii Didascaliei Apostolilor ca operă aparţinătoare comunităţii bosriene, păstrată într-o variantă siriacă, deşi originalul ei trebuie să fie unul grecesc.

\section{Cetăţi şi populaţii încreștinate în spaţiul arab}

Apologia în siriacă adresată lui Caracala, atribuită greşit lui Meliton, biserica şi baptisteriul din Dura-Europos, demonstrează importanţa altui centru creştin din spaţiul siriac, anume Osroene, loc în care apar primele edificii creştine cultuale.

Ghasinizii, populaţie care aparţinea marelui trib arab Azd din sudul peninsulei arabe, au migrat înspre nord, stăpânind Palmyra, sudul Palestinei şi ţinutul Golan. Şi-au stabilit capitala la al Jâbya şi au devenit vasali bizantinilor sub domnia împăratului Atanasie I (491$518)^{17}$, atribuindu-li-se sarcini militare defensive şi supervizarea comerţului. Aceştia au îmbrăţ̧şat creştinismul monofizit în jurul anului 490, iar Biserica monofizită prin eforturile regelui ghasinid, al-Hârith Ibn Jabala a cunoscut o puternică creştere şi o reînnoire în

\footnotetext{
${ }^{14}$ Nicolae Chifăr, Istoria Creştinismului, Volumul I, Sibiu, Editura Universităţii „Lucian Blaga”, 2007, p. 85.

${ }^{15}$ Jean Daniélou, op. cit., p. 231.

${ }^{16} \mathrm{G}$. Kretschmar, Origenes und die Araber, Z.T.K., 50, 1953, pp. 260-264, apud. Jean Daniélou, op. cit., p. 231.

${ }^{17}$ Michel Reeber, Le contexte religieux de l'Arabie préislamique, în „Monde de la Bible", nov., 2002, p. 24.
} 


\section{Oliviu-Petru BOTOI}

acelaşi timp. S-au construit biserici şi mănăstiri şi a existat o misiune foarte puternică în peninsula Arabiei, în acest timp remarcându-se şi doi episcopi, anume Teodorus şi Jacobus Baradaeus ${ }^{18}$. Uşor s-au degradat relaţiile cu Bizanţul, apoi la scurt timp invazia perşilor şi cucerirea Siriei şi a Palestinei de către musulmani, la începutul secolului al VII-lea, au pus în umbră viaţa acestei Bisericii, o parte a credincioşilor convertindu-se la islam, iar alţii alegând refugiul în alte părţi.

O puternică forţă politică, militară şi culturală a fost dinastia arabă a Lakhmizilor, care au domnit în vestul Irakului din secolul al III-lea, până la sfârşitul celui de-al VI-lea şi începutul secolului VII. În plan religios, aceştia au apărat maniheismul până la începutul secolului V, când majoritatea dintre ei s-au convertit la creştinismul nestorian. Convertirea nu a fost deloc una impusă de către clasa conducătoare, doar ultimul rege lakhmiz declarându-se oficial creştin, ci a fost mai degrabă o convertire naturală, datorată misionarilor creştini şi a călugărilor din vremea aceea. Nestorianismul arab a depăşit acest cadrul estului şi nordului Arabiei, ajungând chiar până în India.

Între Arabia Meridională, pe de o parte, şi Abisinia şi Egipt, pe de altă parte, s-au stabilit diferite legături. Populaţia Etiopiei antice era constituită din arabi care au migrat din sudul Arabiei pe continentul african. Începând cu anii 330, creştinismul a pătruns puternic în Etiopia, iar mai apoi, în anul 350, prin decizia negusului Ezana, creştinismul a devenit religie de stat. În secolul VI, prin misiunea călugărilor sirieni, a pătruns în creştinismul etiopian erezia monofizită, rămânând până în zilele noastre caracteristică Bisericii Etiopiei $^{19}$. Statul etiopian creştin a intervenit armat de mai multe ori în Arabia pentru a-i apăra pe creştini. De notat este momentul în

\footnotetext{
${ }^{18}$ Una dintre cele mai de seamă personalităţi ale Bisericii Ortodoxe Siriace. Apelativul de Biserica iacobită îl capătă de la numele acestui episcop.

${ }^{19}$ Christine Chaillot, The Ethiopian Orthodox Tewahedo Church Tradition. A brief introduction to its life and spirituality, s.n., Paris, 2002, pp. 26-34.
} 
care regele himyarit Yûsuf Ash'ar, convertit la iudaism, şi-a propus exterminarea creştinilor din Nâjran şi Yemen. Protectoratul Etiopiei era vizibil în Arabia, însuşi Mahomed recomandându-le adepţilor săi să se refugieze în Etiopia, sau după unii, refugiindu-se pentru o vreme chiar şi el.

O altă Biserică a Orientului care a influenţat religios-doctrinar spaţiul nord-arab este Biserica siriacă, cu prestigiosul centru din Antiohia, unde funcţiona o importantă şcoală exegetică, alături de cea din Alexandria. Tot în acest spaţiu siriaco-arab, au mai existat comunităţi creştine la Damasc, Seleucia, Apameea, Samosata, Bereea, centre creştine care delegat pentru Sinodul I Ecumenic un număr de 20 de episcopi ${ }^{20}$.

$\mathrm{Nu}$ ne-am propus să trecem în revistă toate reperele de spaţiu în care creştinismul şi-a făcut simţită prezenţa, ci am dorit doar să creionăm în linii mari mişcarea religioasă şi teologică care a animat spaţiul oriental (incluzând şi Arabia) în primele secole ale erei creştine. Pot fi date numeroase alte exemple de comunităţi creştine ${ }^{21}$, având diferite moduri de abordare teologică şi cultică, în funcţie de misiunea care a stat la baza lor şi în funcţie de moştenirea religioasă păgână a locului. Spaţiul este destul de întins pentru o radiografie scurtă, iar comunităţile erau destul de eterogene pentru a stabili cu exactitate un tipar anume al creştinismului din teritoriul arabo-siriac. Chiar şi în zilele noastre, acest spaţiu concentrează o listă de Biserici creştine, mici ca număr de credincioşi, însă separate canonic sau chiar dogmatic $^{22}$.

${ }^{20}$ Nicolae Chifăr, op. cit., p. 85.

${ }^{21} \mathrm{O}$ comunitate religioasă desprinsă din creștinism și care a avut un impact puternic în geneza islamului a fost cea a iudeo-nazareilor. Vezi, Edouard MarieGallez, Le messie et son prophete, Aux origines de l'islam, Editions de Paris, 2005.

${ }^{22}$ Ronald Roberson, Bisericile Creştine Răsăritene. O scurtă prezentare, Iaşi, Editura Sapienţia, 2004; Dietmar W. Winkler, Klaus Augustin, Bisericile din Răsărit. O scurtă prezentare, Bucureşti, s.n., 2003. 


\section{Oliviu-Petru BOTOI}

\section{Concluzii}

Prin toate aceste exemple am dorit să surprindem faptul că o bună parte a teritoriului în care în secolul al VII-lea se va dezvolta galopant islamul, a fost loc de misiune roditoare pentru creştini, întemeindu-se adevărate comunităţi. Deşi nu se insistă prea mult asupra acestui spaţiu al creştinismului primar, preferându-se mai degrabă Roma şi Bizanţul, totuşi, creştinismul oriental poate ascunde foarte multe explicaţii ale fenomenelor istorice şi religioase care au urmat.

Una dintre caracteristicile relevante ale creştinismului din acest spaţiu este aceea că era deschis spre orice idee doctrinară nouă, şi ca atare, de cele mai multe ori eretică. Încă de la sfârşitul secolului I şi începutul celui de-al II-lea, existau foarte multe grupări, comunităţi care împărtăşeau idei diferite de propovăduirea ortodoxă.

Spre exemplu, în jurul anului 70, sau după unii chiar cu mult înainte de această dată, exista un grup de iudeo-creştini, care vor fi cunoscuţi sub numele de ebioniţi, şi care împărtăşeau ideea că Iisus Hristos este un simplu om ca şi ceilalţi, $\psi \iota \lambda$ os $\alpha \nu \theta \rho \omega \pi$ tov, care s-a curăţat prin eforturi morale ${ }^{23}$. Probabil că după cucerirea Ierusalimului aceştia încep să-şi caute un alt loc din pricina contextului socio-politic, stabilindu-se ulterior la Pella. Se cunoaşte o scriere care a rămas de la ei, Evanghelia nazarinenilor, datată la începutul secolului II, semn că încă era vie comunitatea şi în secolul al II-lea.

Un alt exemplu demn de luat în seamă este legat de numele lui Elkai (Elkesal, Ilxai), „,care primeşte o revelaţie prin mijlocirea unei cărţi dată lui de către un înger”"24. Cartea este coborâtă din cer, iar cel ce asculta cuvintele ei primea iertarea păcatelor ${ }^{25}$.

${ }^{23}$ Daniel Nicolae Vălean, Erezii, controverse şi schisme în creştinismul secolelor I-XI, Cluj-Napoca, Editura Limes, 2009, p. 14.

${ }^{24}$ Jean Daniélou, op. cit., p. 75.

${ }^{25}$ Milan Şesan, Ereziile iudaizante. Iudeo-gnosticii. Simon Magul, în Pr. Prof. Dr. I. Rămureanu, Pr. Prof. Dr. Milan Şesan, Pr. Prof. Dr. Teodor Bodogae, 
Mai târziu, în secolele III-VI, marile erezii cu care s-a confruntat întreg creştinismul au prins rădăcini puternice pe teritoriile Orientului Apropiat şi Mijlociu. Aşa după cum am putut observa şi în cazul ereziilor de secol I şi II, care nu au avut un ecou puternic în creştinism, ci mai mult au avut un caracter local, de cele mai multe ori cei ce încercau să cunoască creştinismul se poticneau în Persoana lui Hristos ca Dumnezeu adevărat şi Om adevărat. Această neputinţă de a accepta dumnezeirea Fiului a adus divergenţe teologice şi după ce s-au stins confruntările doctrinare cu păgânitatea asiatică, care putea vedea în Hristos mai mult un lider sau un om cu puteri supranaturale care poate vindeca sau învia din morţi. Chiar dacă după Sinodul Ecumenic de la Niceea s-a dogmatizat dumnezeirea Fiului, au apărut mai apoi confruntări teologice legate de structura persoanei lui Hristos, asupra modului în care se poate vorbi despre două firi într-o singură persoană, despre voința umană şi cea divină. După sinoadele ecumenice de la Efes (431) şi de la Calcedon (451), s-au format trei orientări doctrinare: calcedonismul, monofizitismul şi nestorianismul. Doctrina ortodoxă afirma unirea celor două firi, umană şi divină în Ipostasul divin, dar fără ca acestea să se confunde ${ }^{26}$. Cele două erezii extreme, nestorianismul şi monofizismul, care afirmau, pe de o parte o separaţie clară şi fermă între cele două firi ale lui Hristos, ca şi cum în El ,,ar fi două persoane”27, iar pe de altă parte, monofizismul, care afirma „unirea celor două firi până la confundare”28, au câş̧tigat mai

Istoria Bisericească Universală, vol. I, Bucureşti, 1987, pp. 175-176, apud. Daniel Nicolae Vălean, op. cit., p. 17.

${ }^{26}$ Dumitru Stăniloae, Teologia Dogmatică Ortodoxă, Volumul II, Carte tipărită cu binecuvântarea Prea Fericitului Părinte Teoctist Patriarhul Bisericii Ortodoxe Române, Ediţia a III-a, Bucureşti, Editura Institutului Biblic şi de Misiune al Bisericii Ortodoxe Române, 2003, pp. 53-54.

${ }^{27}$ George Remete, Dogmatica Ortodoxă, Ediţia a treia revăzută şi adăugită, Tipărită cu binecuvântarea Înalt Prea Sfinţitului Părinte Andrei Arhiepiscopul Alba Iuliei, Alba Iulia, Editura Reîntregirea, 2000, p. 236.

${ }^{28}$ Ibidem, p. 236. 


\section{Oliviu-Petru BOTOI}

mult teren în spaţiul siro-arab ${ }^{29}$, posibil prin faptul că nucleul acestor erezii a pornit din vecinătatea acestor locuri şi teologia ortodoxă se propovăduia oficial de pe continentul european, din noua capitală a Imperiului Roman de Răsărit. Nu neapărat distanţa faţă de centrul patriarhal a favorizat menţinerea acestor erezii în Bisericile orientale, ci mai mult contextul socio-politic, prin care aceste Biserici ieşeau din sfera politico-geografică a Împeriului Roman sau Bizantin, situânduse la limita dintre aceste imperii creştine şi marile dinastii imperiale ale Orientului Mijlociu. În acest spaţiu, coabitau fără mari dispute doctrinare adepţii lui Mani, zoroastrienii, păgânii arabi, evreii şi nu în ultimul rând creştinii nestorieni, sau monofiziţi în alte părţi. Mai mult decât atât, creştinii marilor oraşe orientale nu erau doar simpli toleraţi, ci erau persoane influente cu responsabilităţi şi funcţii importante în conducerea statului ${ }^{30}$.

\section{Bibliografie}

1. Biblia sau Sfânta Scriptură, Tipărită sub îndrumarea şi cu purtarea de grijă a Prea Fericitului Părinte Teoctist Patriarhul Bisericii Ortodoxe Române, $\mathrm{Cu}$ aprobarea Sfântului Sinod, Bucureşt, Editura Institutului Biblic şi de Misiune al Bisericii Ortodoxe Române, 2002.

2. ***, Dicţionar enciclopedic al Bibliei, Transpunere românească de Dan Sluşanschi, Bucureşti, Editura Humanitas, 1999.

3. Beck, Hans Georg, Istoria Bisericii Ortodoxe din Imperiul Bizantin, Traducere din limba germană şi studiu introductiv de Vasile Adrian Carabă, s. 1., Editura Nemira, 2012.

4. Bunge, Gabriel, Părintele duhovnicesc şi gnoza creştină după

\footnotetext{
${ }^{29}$ Hans Georg Beck, Istoria Bisericii Ortodoxe din Imperiul Bizantin, Traducere din limba germană şi studiu introductiv de Vasile Adrian Carabă, s. 1., Editura Nemira, 2012, pp. 41-50.

${ }^{30}$ Albert Hourani, Istoria popoarelor arabe, Traducere de Irina VainovskiMihai, Iaşi, Editura Polirom, 2010, p. 25.
} 
avva Evagrie Ponticul, Traducere de diac. Ioan I. Ică jr., Sibiu, Editura Deisis, 2000.

5. Chaillot, Christine, The Ethiopian Orthodox Tewahedo Church Tradition. A brief introduction to its life and spirituality, s.n., Paris, 2002.

6. Chifăr, Nicolae, Istoria Creştinismului, Volumul I, Sibiu, Editura Universităţii „Lucian Blaga”, 2007.

7. Cogan, Mordechai, Haym Tadmor, Ashurbanipal Texts in the Collection of the Oriental Institute, în „Journal of Cuneiform Studies", vol. 40, nr. 1, 1988, pp. 84-96.

8. Daniélou, Jean, Biserica primară (De la origini până la sfârşitul secolului al treilea), Traducere din limba franceză de George Scrima, Bucureşti, Editura Herald, 2008.

9. Evagrie Ponticul, Tratatul practic. Gnosticul, Traducere de Cristian Bădiliţă, Bucureşti, Curtea Veche, 2009.

10. Glueck, Nelson, Nabatean Syria, în „Bulletin of the American Schools of Oriental Research, nr. 85, feb., 1942, pp. 3-8. Chrystian Boyer, Pétra, capitale des Nabatéens, în „La Caravane virtuelle", 26 mai 2006, articol consultat la adresa web http://www.interbible.org/interBible/caravane/voyage/2006/ voy_060526.htm).

11. Hastings, James, Dictionary of Christ and the Gospels, II, New York, Charles Scribners Sons - Edinburgh, T \& T Clark, 1908.

12. Hourani, Albert, Istoria popoarelor arabe, Traducere de Irina Vainovski-Mihai, Iaşi, Editura Polirom, 2010.

13. Pelikan, Jaroslav, Tradiţia creştină. $O$ istorie a dezvoltării doctrinei. Vol. I: Naşterea tradiţiei universale (100-600), Traducere de Silvia Palade, Iaşi, Editura Polirom, 2004.

14. Reeber, Michel, Le contexte religieux de l'Arabie préislamique, în „Monde de la Bible”, nov., 2002.

15. Remete, George, Dogmatica Ortodoxă, Ediţia a treia revăzută şi adăugită, Tipărită cu binecuvântarea Înalt Prea Sfinţitului Părinte Andrei Arhiepiscopul Alba Iuliei, Alba Iulia, Editura Reîntregirea, 2000.

16. Roberson, Ronald, Bisericile Creştine Răsăritene. O scurtă prezentare, Iaşi, Editura Sapienţia, 2004.

17. Royalty Jr., Robert M.., „Heresy” in Second-Temple Judaism 


\section{Oliviu-Petru BOTOI}

and Early Christianity, în „Concilium”, Christian Orthodoxy, nr. 2, 2014, pp. 38-39.

18. Starcky, Jean, The Nabataeans: A historical Sketch, în „The Biblical Archaeologist", vol. 18, nr. 4, dec., 1955, pp. 81-106.

19. Stăniloae, Dumitru, Teologia Dogmatică Ortodoxă, Volumul II, Carte tipărită cu binecuvântarea Prea Fericitului Părinte Teoctist Patriarhul Bisericii Ortodoxe Române, Ediţia a III-a, Bucureşti, Editura Institutului Biblic şi de Misiune al Bisericii Ortodoxe Române, 2003.

20. Şesan, Milan, Ereziile iudaizante. Iudeo-gnosticii. Simon Magul, în Pr. Prof. Dr. I. Rămureanu, Pr. Prof. Dr. Milan Şesan, Pr. Prof. Dr. Teodor Bodogae, Istoria Bisericească Universală, vol. I, Bucureşti, 1987.

21. Verzan, Sabin, Sfântul Apostol Pavel. Istoria propovăduirii Evangheliei şi organizării Bisericii în epoca apostolică, Carte tipărită cu binecuvântarea Prea Fericitului Părinte Teoctist Patriarhul Bisericii Ortodoxe Române, Bucureşti, Editura Institutului Biblic şi de Misiune al Bisericii Ortodoxe Române, 1999.

22. Winkler, Dietmar W., Klaus Augustin, Bisericile din Răsărit. $O$ scurtă prezentare, Bucureşti, s.n., 2003. 